\title{
Discussion on the Effective Application of Information Technology in Informatization EFL Teaching ${ }^{*}$
}

\author{
Zhaoxi Wei \\ Beijing Information Technology College, Beijing, China
}

\begin{abstract}
The Integration of information technology and EFL teaching has become inevitable. Based on the development of information technology and the improvement of Informatization Teaching Environment, the cognition of informatization teaching competency and the exploration of informatization EFL teaching mode keep pace with the times. This paper discusses the effective application of information technology in informatization EFL teaching from perspectives of times' interpretation of informatization EFL teaching, informatization teaching competency and practice of informatization EFL teaching mode. Through empirical research on informatization EFL teaching mode, this paper proposes that the effectiveness of informatization EFL teaching mode depends on more attention to students' individual differences in the implementation of the information-based teaching mode as well as to the construction of diversified interactive platforms under the informatization EFL teaching mode. And the more flexibly the information technology is applied to EFL teaching, the more effectively the informatization EFL teaching mode makes up for the students' individual differences in learning, learners of autonomous learning can engage themselves in interactive teaching consciously and actively to cultivate their autonomous learning ability and make satisfactory achievements.
\end{abstract}

Index Terms - information technology, EFL teaching, informatization teaching competency, informatization teaching mode

\section{INTRODUCTION}

Information technology is the most popular topic in the 21 st century. It is often praised as a synonym for "digital age", 'Internet age" and "knowledge society". Combination of information technology and EFL teaching makes them a must in applying and researching information technology into EFL teaching, to understand the relevant concepts with times, to interpret the informatization teaching competence as well as the effect of practice of blended teaching mode.

\section{ANALYSIS AND DisCUSSION}

\section{A. The Interpretation of Application of Information Technology in EFL Teaching from the Perspective of the Times}

Firstly, the application of information technology in EFL teaching creates an information environment for EFL teaching. The information environment is supported by network technology. Specific means based on informatization infrastructure construction show such features of digital learning environment as the information display multimedia, intelligent information processing, information transmission networking and learning environment virtualization. The informatization teaching environment includes the hardware environment of building and using modern education media, such as simulation software, network courses and teaching platforms. It also includes the creation and use of soft environment such as learning atmosphere, situational cognition environment, personnel informatization capacity and literacy. Information-based teaching environment refers to the use of modern education media for teaching activities between teachers and students, which are teaching activities between teachers and students based on information technology and are the two-way mutual activity between teacher's teaching and students' learning (Jiang, 2015). Informationization refers to EFL teaching carried out during the process of comprehensive and in-depth use of computer, through multimedia and it regards network technology as the core of the modern information technology to optimize the process of EFL teaching, to improve EFL teaching quality and effect, to reform the traditional teaching concept and methods. Thus, Informationization is the process of organic integration of foreign language courses with information technology. Since the core of information technology is network, the core features of network are interconnection and information sharing, then EFL teaching under the information environment is mainly the interactive teaching activities assisted by information in the network environment.

"Learning to learn" has become the ultimate goal of people's development on the premise that the education concept of learner-centered is deeply rooted in people's minds. The practice of information technology in EFL teaching has also

\footnotetext{
* This paper is the research-oriented achievement of established projects of Beijing Education and Teaching Reform in 2015 (Project No.2015-MS217); the phased achievement of established BITC project (Project No.XY-YN-201618).
} 
experienced a trend from computer-aided teaching, network autonomous learning, mobile language learning to ubiquitous learning. Learning approach has developed from digital learning, mobile learning, ubiquitous learning, individualized learning to lifelong learning. The development of the network and the innovation and popularization of mobile terminal product benefit the foreign language learners to use such mobile terminals as smartphones, tablets and other electronic products anytime and anywhere to do searching for language learning through the wireless Internet. With the development and improvement of $\mathrm{WiFi}$ and micro-terminals, the development and promotion of micro-courses, micro-video, micro-courseware and MOOC, ubiquitous learning is becoming a new trend in the development of digital learning. Among them, there is no lack of individualized autonomous learning activities in foreign language carried out by learners using different terminals, based on online teaching platforms, learning websites and teaching software, etc. Informatization of EFL teaching practice, therefore, is to keep pace with the Times and the occasion, deeply integrating the information technology with EFL teaching, fully displaying the effect of information technology on EFL teaching, promoting the network as the foundation and interactive mechanism to establish the meaning framework under the network environment to cultivate students' learning autonomy, creativity and competency of learning to learn.

Networked learning environment, digital learning resources and diversified learning styles have greatly changed the teaching mode from a piece of chalk, a textbook and a blackboard in the traditional way, to the teaching mode under the information technology support from the early multimedia EFL teaching mode, the network teaching mode, the blended teaching model under the information technology support. Mainly based on the teaching approaches, such as the problems -probing approach, the network-inquiring approach, the group-collaborating approach, the task -basing approach and so on, EFL teaching is organized and conducted through the association of being online and being offline, the combination of being inside and being outside the classroom and the blend of teachers' face-to-face teaching and learners' autonomous learning. As the development and application of information technology, such as Internet, the Internet of things, big data, cloud computing, wearable smart devices, the following technical service forms appear: foreign language courses for class/micro teaching platform, the smart learning platform, the network learning community, smart classroom, which contributes to the construction of the modes of information classroom teaching in the Internet + era. Due to the wide application of information technology, the classroom teaching approach and learning approach of foreign language are changing considerably: individualized teaching mode is created in accordance with the actual requirement of students, which promotes the development and construction of the course and realizes the organic integration of the course construction with the smart technology, the integration among the teaching, the learning, the media and resources. Thus, new ecological combination of EFL teaching is formed, that is, normalized online classroom, ubiquitous autonomous learning, and intelligent organization management.

It can be said that EFL teaching mode supported by information technology has gradually benefited teachers, ideally, to normalize the language learning assisted by information technology. Secondly, with the aid of the teaching platform and the application of APP in smart phone, the functions of teaching assistant and learning aid are under improvement, and the optimization of teaching for teachers are under go, such as the implementation of just-in-time teaching feedback, the optimization of teaching design, the variation of teaching interactive tasks, the diversification of teaching evaluation as well as the transformation of network resources into teaching resources, etc., to realize the integration among teaching, learning and assessment, the visualization and digitization.

\section{B. The Interpretation of Application of Information Technology in EFL Teaching from the Perspective of Informatization Teaching Competency}

The above analysis interprets the timeliness and inevitability of the development of EFL teaching under the support of information technology. In the process of EFL teaching informatization, information technology is only an auxiliary teaching approach, not a teaching objective. Secondly, the informationization teaching and traditional classroom teaching are quite different in terms of teaching organization and management, and information technology does not apply to the whole process of EFL teaching, informationization teaching and classroom teaching are still compatible with and complementary to each other (Wang, 2016). In foreign language teaching, information technology and information equipment can never completely replace the role of teachers. However, in the process of information technology application to the teaching, the existence of the following misunderstandings need to re-examine the informationization teaching competency to deepen the understanding of the information technology application in EFL teaching:

1) Application objective of information technology in EFL teaching. The misunderstanding is: the more complex the information technology, the higher the cost, the better. Information technology is to beautify education function. In order to clarify such misunderstanding, the idea of combining the information technology with the EFL teaching should be rooted in our minds, to promote the information technology into the classroom, into the students learning process. The application of information technology to the teaching aims to be "practical, enough, appropriate". As Jiang (2015) states: "though the impact of modern information technology on the education is limited, the effect of the talent training is meaningful. In the information environment, the integration of information technology into the classroom teaching optimize optimizes the teaching process, enhances students' learning initiative, autonomy and enthusiasm and improves the learning efficiency." (p.31).

2) Application value of information technology in EFL teaching. The misunderstandings are: in multimedia and online classes, too much attention to and reliance on information technology, too much emphasis on man-machine 
interaction, too little attention to the emotional cultivation of students, lacking novelty in the teaching content, the abuse of media, the display of equipment in the teaching process, overloaded Information to distract students and lack of teachers' guidance, monitoring and effective evaluation in students' self-learning (Wang, 2016). In view of the above value misunderstanding, it is necessary to establish the idea that "teachers are the key to improve the quality of English teaching in EFL environment." (Zhou, 2010, p.18).Therefore, for foreign language teachers under the environment of informatization, information technology is effective to conduct interactive teaching. And to make the best use of it and to make the appropriate us of it are the premise of effective interactive teaching, which requires teachers to change their roles under the environment of informatization. The roles change from the authority of the classroom teaching to the designer and the organizer of individualized learning activities; from the feeder cramming teaching materials into students' minds to the guidance of information resources and the maker of high-quality teaching resources; from the top commander of classroom teaching to the assistant to students' learning, the creator of independent learning situations and the cultivator of students' independent learning competency.

3) Application effect of information technology in EFL. Information technology application in EFL teaching can't focus too much on the construction of hardware and software resources and the operation of technology. The focus should be transferred to the three effects, namely, the effect of information technology application to the inside and outside of the classroom, the learners' learning effect after use and the teaching effect using technology.

4) Misunderstanding of teaching competency in the application of information technology to EFL teaching. It is wrong to simply think that the informatization teaching competency is the multimedia teaching, which uses WORD, PPT and other office software to complete the production and demonstration of teaching courseware, as well as conducts online answering questions for students on BBS etc. In fact, the informatization teaching competency is the application ability of information technology to EFL teaching. In addition to the basic computer application skills, multimedia courseware production skills, the use of electronic teaching equipment in foreign language teaching, etc., to launch the course construction of the network, to use the network teaching platform system, to integrate teaching resources, to reasonably choose the forms of presenting teaching resources, to conduct micro class design and production, to practice flipped- classroom, and so on, are the need to have a certain information-based teaching comprehensive competency. The information-based teaching comprehensive competency, to be specific, are: information technology teaching ability, the informationization teaching design ability, the informationization teaching resources development ability, information assessment and teaching interaction ability, and information teaching cooperation ability (Li, 2013, p.45).

C. The Interpretation of Application of Information Technology in EFL Teaching from the Perspective of Practice of Informatization EFL Teaching Mode-BITC as the Case

1) Interpretation of Feasibility of the Informatization Teaching Mode of Public English in Beijing Information Technology College.

Beijing Information Technology College (BITC) has the following feasibility to carry out the informatization teaching of public English:

a. Informatization set-up of teaching environment: campus network is fully covered with Wi-Fi and with stable operation; online course learning system is established for all courses; network learning environment provides all-round services for students' independent learning as well as teachers' sharing teaching.

b. Informatization technology training for and practice of teaching staff: thanks to Teacher Development Center, informatization instructional design training as well as hardware and software application training provide powerful support for cultivating teachers' information technology teaching consciousness and ability. At the same time, being a teaching task, full-time teachers of the college actively participate in the construction of the ubiquitous learning platform of relevant courses, the construction and improvement of online courses, and the development of online teaching of courses. Take foreign language teachers as example, a total of 186 course projects involves a platform for online courses, online standard library, online teaching micro-courses, etc. The upload resources, the course online platform and micro-courses facilitate the student to study anytime and anywhere and the teacher to get feedback and conduct evaluation timely.

c. Informatization embodiment in micro-course design and production competition as well as of informatization class teaching competition: 26 works of foreign language teachers were awarded in the teaching competition of design and production of micro-courses. In addition, 12 teachers of Public English participated in the informatization class teaching competition with good awards. At the same time, national micro-course teaching competition of colleges and universities, Beijing higher vocational colleges teaching design competition and college informatization class teaching design competition provide foreign teachers with growing-up platform and developing opportunities in informatizaiton teaching, informatization design and information technology application.

d. Informatization practice of innovative teaching mode based on network platform and mobile terminal. Under the informatization environment, foreign language teachers conduct the operation of flipped classroom, in which they make full use of the MOSOTEACH App to develop the interactive teaching mode with instant feedback inside and outside the classroom and design the teaching activities in the informatization teaching environment. In addition, the department of foreign languages cooperated with Technology Application Institute to develop the EFL training platform that has been put in practice in 2015 and in 2016, which fully embodies the interaction between teachers' guidance, resources for 
learning and students' autonomy learning under the network environment, between knowledge presentation and innate skill acquisition. It can be said that information technology does guarantee EFL teaching the teacher with informatization teaching competency, the strong technical support, the convenient platform and flexible means.

2) Practice of Informatization EFL Teaching Mode under Information-based Environment

EFL teaching informationization is the embodiment of the application of information technology in EFL teaching, which runs through 20- year development and is divided into three categories: one is "Internet + Network Course Platform", mainly meeting the needs of network remote education and network learning; the second is "Internet + Video Teaching + Teacher-Student Interaction", which focuses on the sharing of high-quality teaching resources and the needs of online learning; the third is "Internet + blackboard + mobile terminals" (Tao, 2017). Among them, the first requires the school to make a big effort to build or purchase the online course platform, which is large in scale, in strength and in investment for school but not applicable for the individual teacher. The second requires teachers to optimize teaching activities and promote design and the third is portable and flexible for its mobile terminal. If teachers use mobile terminals to carry out interaction, the control and the rhythm in the process of teachers' classroom teaching will be enhanced to stimulate students' classroom presence and engagement, to realize the collection of teaching behavior and the feedback of students' learning condition, which will be beneficial to the formative assessment. As shown in Fig. 1

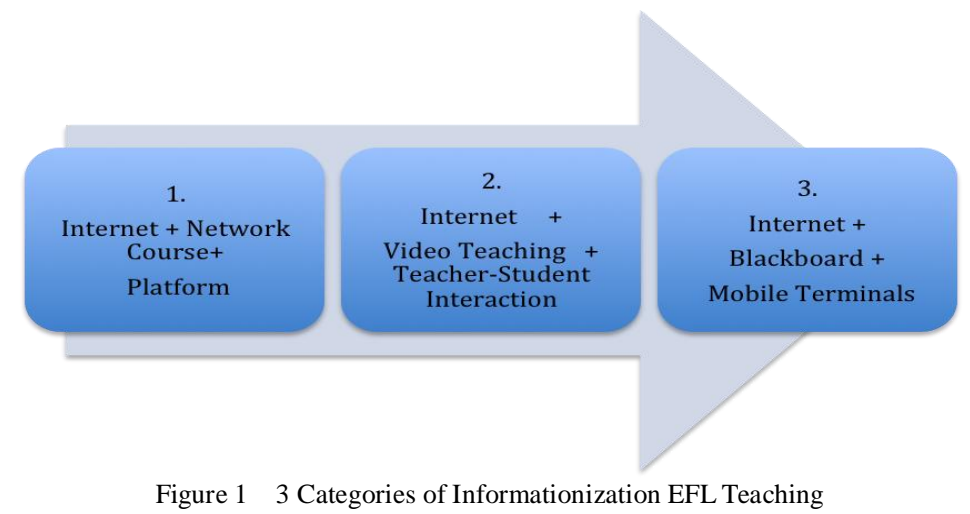

Beijing Information Technology College, since 2012, has been implementing information teaching and constructing the network environment. Based on the "Internet ++ network course platform", the college adopts network teaching platform to train students' learning autonomy, such as the multimedia classroom, the network classroom, the autonomous learning platform and Longman Interaction English software etc.. The following teaching mode is 3-phrase mode, that is, "pre-class platform autonomy + in-class diagnosis teaching + after-class platform autonomy". For Listening and Speaking Unit, "2+2+... " Mode is available (4 consecutive hours for 2 independent hours before class, 2 hours of classroom teaching. The rest of the exercises and practice is required to be completed off the class before the deadline. For Reading and Writing Unit is " $2+\ldots$ "Mode ( 2 hour for face-to-face classroom teaching discussion, the rest for students' autonomous learning before the set time). The 3-phrase Mode teaching is available in multimedia classroom, computer room and classroom.

Internet autonomous learning platform offers students an open, diversified mode of autonomous learning, indulging students in an independent and autonomous environment to conduct language practice, to acquire learning skills, to select the appropriate materials, to evaluate the learning performance for themselves, which bring students too much autonomy to decide on, much motivation to study and satisfaction to enjoy. By comparison, Ismart intelligent interactive learning platform is with more funny and diverse evaluation methods, Longman interactive software is with more diversified and various studying materials. In addition, more updated data and feedback of learning process and behavior from platforms stimulate students' potential to keep on studying and on challenging. However, tedious technical operation of man- machine dialogue for hours is prone to burnout and loss of interest, for the lack of emotional face-to-face communication, of active learning atmosphere, of mutual support of learning companions. Therefore, based on the above features of autonomous learning mode, the informatization teaching mode is complemented by promoting the interaction between the teachers and students, integrating features of the second and the third category. And the reformed teaching mode, "Internet + Mobile + Interaction Design" focuses on "interaction" by adopting the commonly- used mobile terminal learning APP, as shown in Fig. 2:

\begin{tabular}{|l|l|}
\hline Learning Apps & 1. MOSOTEACH App \\
\cline { 2 - 3 } & 2. ISMART Platform App \\
\cline { 2 - 3 } & 3. A+ Classroom App \\
\hline & 4. Rain Classroom App \\
\cline { 2 - 2 } & 5. Micro Assistant App \\
\cline { 2 - 2 } & 6. Examcoo App \\
\cline { 2 - 2 } & 7. Wenjuan App \\
\cline { 2 - 2 } & 8. Pigai App \\
\hline
\end{tabular}

Figure 2 Learning APPs used at Mobile Terminal 
Informatization teaching with App is a lightweight solution of the intelligent teaching as well as a new interactive teaching tool, transferring the experience-driven teacher to data-driven teacher and promoting the development of teacher-student interaction mode in EFL teaching with the support of information technology:

a. To create a class, to make votes and to do online tests are the teacher-student interaction with APP. Especially online test database realizes the combination of examination and teaching at any time to track learning behaviors and the separation of teaching and examination to expand learning scope.

b. To manage teaching intelligently. Attendance, grouping and interaction activities are conducted with APP, quiet pressing button but busy engagement and active participation in interaction enables teachers to keep elegance in teaching organization, the elegance of control and of rhythm in teaching management.

c. To stimulate students' interest and participation in diversified interactive activities. Diverse ways of participation (voice, picture, video, text message) have confirmed the students' sense of existence, their presence and their engagement in interaction.

d. To make effective teaching with high efficiency. The learning process and the learning behavior are shown in the form of big data, which makes the teaching more specific and more focused as well as the teachers more concentrated on the individual problems to solve, the concrete questions to answer and the difficulties to get through.

e. To make learning persistence and learning autonomy possible. Courseware, resources, teachers, activities are all parts of teaching and learning interaction, no matter being online or offline, being inside or outside of the classroom. Students' learning interest and learning enthusiasm are turned into learning motivation with the aid of APP, and turns studying into part of life unconsciously.

So to speak, information-based EFL teaching offers teachers a variety of teaching practice, which in turn brings students different experience, feelings and reaction. Thus, informatization teaching enhances variety of interaction, diversity of teaching mode and autonomy of learning.

3) Conclusions of Empirical Research on the Informatization EFL Teaching Mode of Beijing Information Technology College

After two years of study on information-based teaching mode practice, it is found that interactive teaching can improve the learning effect. In the research, paired $\mathrm{T}$ test is used to detect whether there was a significant difference between the pre-test and the post-test (Practical English Test for Colleges, that is, B-level in this paper) of the sampled class after the optimized information-based teaching mode. Correlation analysis is used to detect correlation between the results of autonomous learning outcomes, academic achievement and the B-level score.

a. Paired samples test between pre-test and post-test and its results

The sample classes in the study are class 1624071 and class 1625021 . Paired samples tests for class 1624071 and class 1625021 are between pretest and posttest (B test), and the results are as follows: Table 1 shows that the pretest of class 1624071 is significantly different from its posttest(Btest) $1624071(\mathrm{t}=-3.978, \mathrm{df}=24, \mathrm{p}<0.05)$, the score of pre-test is significantly lower than that of post-test ( $\mathrm{MD}=-15.520)$; Table 2 shows that the pretest of Class 1625021 is significantly different from its post-test $(\mathrm{t}=-3.978896, \mathrm{df}=26, \mathrm{p}<0.05)$, the score of pre-test is significantly lower than that of post-test $(\mathrm{MD}=-18.556)$.

TABLE 1

RESUlt OF PAIRED SAMPLES TEST BETWEEN PRE-TEST AND BTEST (POST-TEST) OF Class 1624071

\begin{tabular}{|c|c|c|c|c|c|c|c|c|}
\hline & & & & \multicolumn{5}{|c|}{$\begin{array}{l}\text { 95\% Confidence } \\
\text { Interval of the } \\
\text { Difference }\end{array}$} \\
\hline & Mean & $\begin{array}{l}\text { Std. } \\
\text { Devation }\end{array}$ & $\begin{array}{l}\text { Std. Error } \\
\text { Mean }\end{array}$ & Lower & Upper & $\mathrm{t}$ & $\overline{\mathrm{df}}$ & $\overline{\text { Sig.(2-tailed) }}$ \\
\hline Pair1 pretest-Btest & -15.520 & 19.507 & 3.901 & -23.572 & -7.468 & -3.978 & 24 & .001 \\
\hline
\end{tabular}

TABLE 2

RESUlt OF PAIRED SAMPLES TEST BETWEEN PRE-TEST AND BTEST (POST-TEST) OF ClASS 1625021 Paired Samples Test (1625021)

\begin{tabular}{|lllllllll|}
\hline & \multicolumn{1}{c|}{$\begin{array}{l}\text { 95\% Confidence } \\
\text { Interval of the } \\
\text { Difference }\end{array}$} \\
\cline { 2 - 9 } & Mean & $\begin{array}{l}\text { Std. } \\
\text { Devation }\end{array}$ & $\begin{array}{l}\text { Std. Error } \\
\text { Mean }\end{array}$ & Lower & Upper & t & df & Sig.(2-tailed) \\
\hline Pair1 pretest-Btest & -18.5556 & 24.769 & 4.7625 & -28.3451 & -8.7660 & -3.896 & 26 & .001 \\
\hline
\end{tabular}

The paired samples test results above indicate that the informatization interactive EFL teaching mode can indeed improve the teaching effect. Among them, the average post-test (B-level) score of the sampled class 1624071 increases by $78.5 \%$ compared with its pretest score, and its passing rate of B-level examination increases from $20 \%$ to $60 \%$. The passing rate of sample class 1625021 reaches $80.77 \%$, which increases by $30.43 \%$ compared with its pretest score. Under the informatization teaching mode, students have achieved success in learning and gained achievements in learning.

b. Relation Analysis of Sampled Class among Autonomous Learning Outcomes, Academic Performance and National 
College English Examination (B-level) scores:

EXCEL summarizes autonomous learning achievement, academic achievement and the National College English Examination (B-level) score of the sampled class, revealing the correlation among autonomous learning outcomes of the interaction feedback, semester scores (academic achievement )and scores of B-level. As shown in Figure 3 and Figure 4, the variation trends of three curves of the sampled class remains the same, which illustrates: under the informatization interactive teaching mode, the autonomous learning process which is the formative performance is consistent with the score of academic achievement that is summative performance, which means a positive correlation between them. With the aid of interaction under the information-based teaching mode, the students generally value the accumulation of interaction experience or daily interaction outcomes, and they show great interest in engaging in a variety of interactive activities for selecting and processing resources, for giving feedback to interaction, for participating in related activities and then their autonomous learning outcomes are shown in data for teachers to observe students' daily learning performance. And the curve representing process of learning (autonomous learning outcomes) fluctuates in consistent with that of academic performance, showing autonomous learning achievement at ordinary times, namely the procedural learning, has positive effect on the academic performance. Therefore, daily autonomous learning through the interactive activities will cause the accumulation of formative outcomes, which exerts the positive and active effect on the summative academic performance and satisfactory B-level score. (in the Fig.3 and Fig. 4, 学期 学业成绩= academic summative performance; 经验值= autonomous formative learning outcomes)

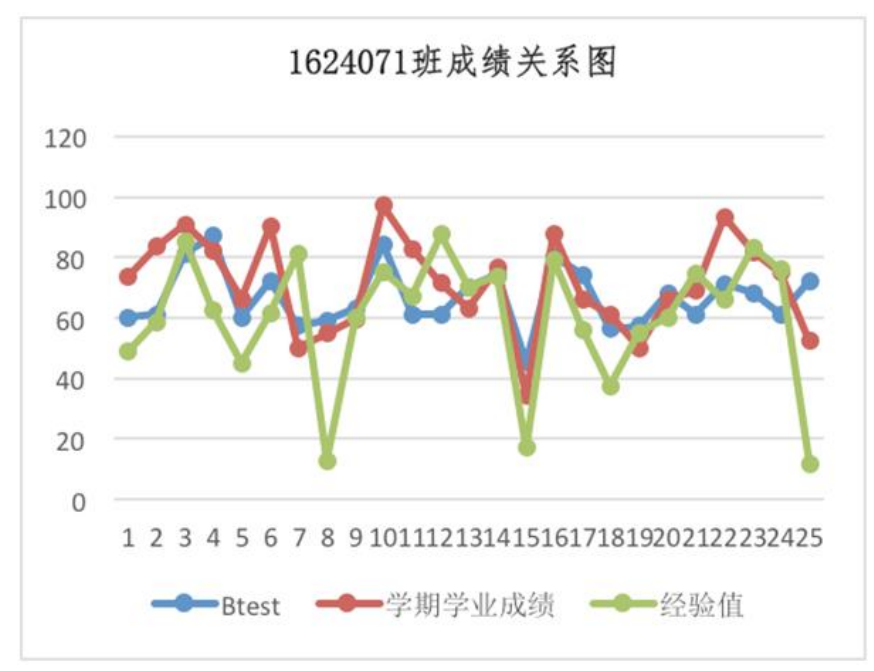

Figure 3 Relation Analysis of Class 1624071

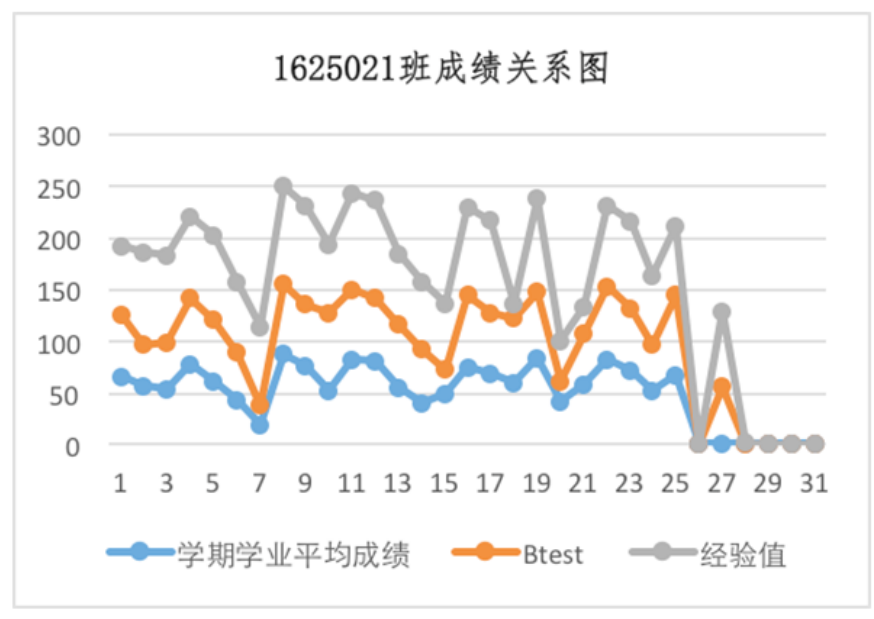

Figure 4 Relation Analysis of Class 1625021

c. Self-Adaptive Adjustment of Students' Autonomous Learning under the Informatization EFL Teaching Mode:

In the study, it was found that due to individual cognitive differences, learners have differences in adaptive learning rhythm under the network environment and differences in participation achievements and autonomous performance. But along with the implementation of informatization EFL teaching mode, students will gradually adjust their learning habits, which contributes to their autonomous learning performance and their substantial progress in autonomous learning outcomes. In addition, by re-setting the learning goal and adopting appropriate learning strategy, they can keep on learning aided by informatization. Therefore, under the informatization environment, the core of student-centered 
idea is the embodiment for students to make adjustment autonomously, to take part in activities spontaneously, to make active feedback to learning, to make their choices on their own, letting learner learn anytime and anyplace.

Therefore, the empirical research on the informatization EFL teaching mode shows that:

(1) The autonomous learning effect is reflected not only on the improvement of academic performance, but also on learners' adaptive length of time and their adaptive speed during the informatization autonomous learning process. Therefore, we need to pay more attention to students' individual differences in the implementation of the information-based teaching mode, and to offer diversified interactive platforms under the informatization EFL teaching mode for students' to adjust, to adapt, to participate and to choose what are suitable for them, gradually cultivating the students' adaptability, independent learning ability and the ability of learning to learn, which shows the effectiveness of informatization EFL teaching mode (Wei, 2017).

(2) The more flexibly informatizaiton aids EFL teaching, the more effectively informatization EFL teaching mode makes up for the students' individual differences in learning, the more autonomously learners participate in the interaction, the more consciously they engage themselves in learning, the better they make formative performance as well as summative achievement.

(3) Only if the student is as the center under the informatization EFL teaching mode, can we succeed in cultivate the student autonomous learning ability and make satisfactory teaching achievements.

\section{CONCLUSION}

The cognition of application of information technology in EFL teaching is developing with the times. With the development of information technology, it constantly enriches EFL teaching competency, optimizes the informatization EFL teaching mode, and promotes the interaction between and complements with teaching and learning under the environment of information technology. Therefore, the effective application of information technology in informatizaiton EFL teaching depends on more attention to students' individual differences in the implementation of the information-based teaching mode as well as to the construction of diversified interactive platforms under the informatization EFL teaching mode. And the more flexibly the information technology is applied to EFL teaching, the more effectively the informatization EFL teaching mode makes up for the students' individual differences in learning, learners of autonomous learning can engage themselves in interactive teaching consciously and actively to cultivate their autonomous learning ability and make satisfactory achievements.

\section{REFERENCES}

[1] Jiang Liping. (2015).Transforming Traditional Teaching with Modern Information Technology—Thoughts triggered by the Informatization National Vocational College Teaching Competition. Industry and Information Technology Education, 8, $26-31$.

[2] Li Tianlong.(2013).An Analysis on Components of Information-based Teaching Ability of University Teachers. Contemporary Teacher Education, 6, 44-47.

[3] Tao Chun. (2017). Mobile Broadcast NOT a Feast of "Web Celebrity". China Education Network, 5, 17-19.

[4] Wang Fengming.(2016). Research on Informatization Foreign Language Teaching in Colleges and Universities. China Education Informatization, 4, 40-44.

[5] Wei Zhaoxi. (2017). Empirical Research on the Interactive Effectiveness of EFL Teaching under the Network Environment. Science and Technology, 20, 51-52.

[6] Zhou Yan. (2010).Teachers, the Key to Improve English Teaching in Foreign Language Learning Environment. Foreign Language Teaching and Research, 4, 17-23.

Zhaoxi Wei was born in Shanxi, China in 1975. She received her M.A. degree in Cross-Culture Studies from Beijing International Studies University, China in 2006.

She is currently an associate professor in Beijing Information Technology College, Beijing, China. Her research interests include cross-culture studies, informatization English teaching and research.

Prof. Wei is a member of the National Association of Foreign Language Education of China Education Society. 